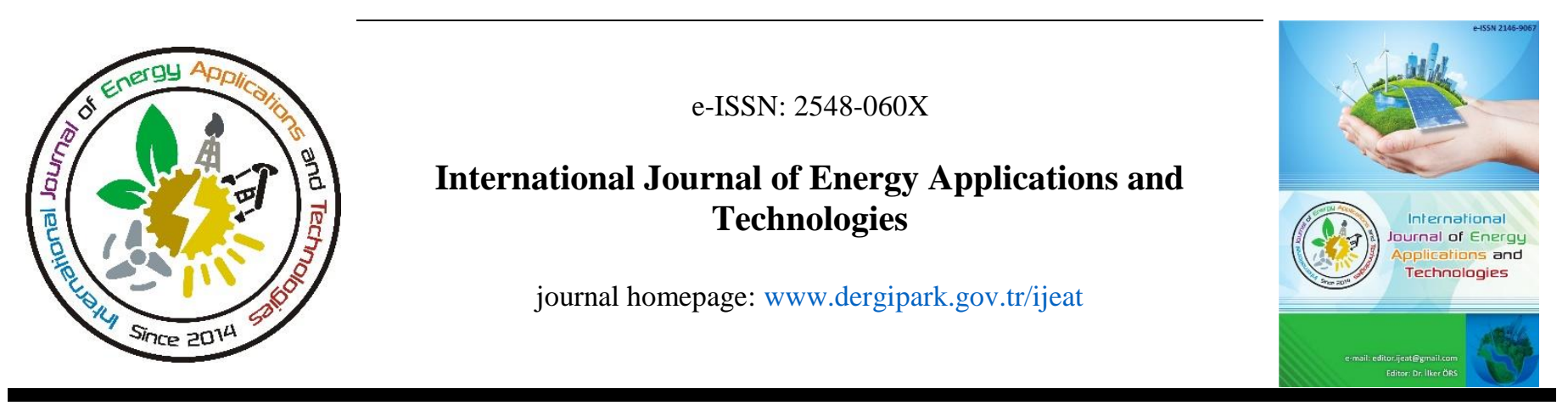

Original Research Article

\title{
Evaluation of the energy potential of cow dung in microbial fuel cell for micro- power applications in Nigeria
}

\author{
Nosakhare Agho*, Ikpe Aniekan E. Sadjere E.G., Rogers Tamuno \\ Room 142 Mechanical Engineering Department, University of Benin, Nigeria
}

\author{
ARTICLE INFO \\ * Corresponding author \\ nosaoasis@gmail.com \\ Received May 24, 2018 \\ Accepted September 23, 2018 \\ Published by Editorial Board \\ Members of IJEAT \\ (C) This article is distributed by \\ Turk Journal Park System under \\ the CC 4.0 terms and conditions.
}

doi:10.31593/ijeat.426846

\begin{abstract}
In this study, three mediatorless chamber microbial fuel cells were built and experiments were carried out using a mixture of cow dung and water. The volume of the mixture in each cell was $5309440 \mathrm{~mm}^{3}$ and the ratio of the surface area of aluminum anode electrode to graphite rod cathode electrode was $2: 1$. The maximum open circuit voltage and current obtained was $0.73 \mathrm{~V}$ and $10.87 \mathrm{~mA}$ respectively. Maximum total voltage and current obtained for the period of 28 days under investigation was $14.4 \mathrm{~V}$ and $168.1 \mathrm{~mA}$. The average total voltage and voltage drop during the period under investigation were $14.59 \mathrm{~V}$ and $0.4 \mathrm{~V}$ respectively. The average power rating per day produced from the each cell was $143.47 \mathrm{mAH}$. This study has shown that cow dung is a potential substrate for energy generation using a single chamber Microbial Fuel Cell (MFC).
\end{abstract}

Keywords: Energy, Microbial Fuel Cell, Single Chamber, Cow Dung, Micro-power, Current

\section{Introduction}

Most organic substance in nature has stored in itself inherent energy which can be harnessed and transformed to a different form of energy. In nature, the different forms of energy are available in different amount creating an energy balance that sustains the environmental conditions suitable for human and animal life [1]. Nigeria generates less than 10000MW of electric power daily for her citizens of over 180 million.

Power generation in Nigeria for the past two decades has been epileptic, erratic and unreliable. It is estimated that $50.45 \%$ of energy consumed is fuel wood, $5.22 \%$ from natural gas, $3.05 \%$ from hydroelectricity and $41.23 \%$ from petroleum products. The energy consumption in Nigeria is split between hydroelectricity and fuel wood [2, 3]. Nigeria needs more energy for development and must begin to use resources which are renewable, available, sustainable and environmentally friendly. According to [2], Nigeria generates organic waste of between 26-32 million tonnes annually out of which $20-30 \%$ is collected by waste managers. With the increasing population in Nigerian, there is a corresponding increase in the amount of waste generated resulting in environmental degradation and public health risks as a result of the improper waste management in most parts of the country $[4,6]$.

Over the years, waste has generally been regarded as unwanted and unusable material that needs to be disposed [9]; however, countries are now beginning to see waste as a resource $[5,8,11]$. Nigerian markets generate a variety of wastes, for example, corn cobs, vegetable wastes and packaging materials. Unchecked and untreated waste adds to the continued environmental dilapidation from the use of non-renewable energy sources for power generation, making the topic of waste management, oil depletion and climate change a major concern amongst world leaders [12, 13, 14]. Continuous research on ways to minimize energy consumption and using renewable energy resource to meet 
energy demand is being undertaken by scientists, researchers and engineers around the world. Nigeria is a society with various culture, religion and beliefs and waste is generated at the rate of $0.43 \mathrm{~kg} / \mathrm{head}$ per day and $60-80 \%$ of it is organic in nature [6].

Most wastes can be recycled for energy, a process known as Waste to Energy (WTE) as they contain valuable resource, most important is energy. Various methods of converting waste materials to energy include combustion, pyrolysis and gasification. The energy can be recovered and this process is called Energy Recovery [10]. The Microbial Fuel Cell (MFC) is an Energy Recovery equipment used to harness the stored energy in organic matter. MFC is a bioreactor that coverts the chemical energy stored in organic matter directly in electrical energy. Treatment of organic waste is energy demanding and it produces large amount of waste that requires additional cost to treat and dispose [15]. The MFC requires zero energy input and has a high energy conversion ratio (>70\%) [7]. The energy obtained from MFCs can be used for specially designed domestic purposes like powering of micro power equipment e.g. road traffic lights and reading lamps.

There are basically two designs of the MFC namely; Single Chamber Design and the Two-Chamber Design as shown in Figure 1. Like the two-chamber MFC, the single chamber MFC has two electrodes (anode and cathode); however, the single chamber MFC does not require an Ion Exchange Membrane (IEM) to collect and transfer electrons from the inner walls of the microbes to the anode electrode $[16,17]$. The single chamber consists of two electrodes, having different potential difference (PD) and good electrical conductivity totally or partially immersed in organic matter. The single chamber MFC can also be set up using same electrode material; however, the anode electrode is wholly immersed in the organic matter as shown in Figure 1a. The cathode can be in direct contact with air either in the presence or absence of a membrane [4, 5]. The electrodes are connected via conducting wire. During the process of organic decomposition in the MFC, there are reactions which takes place i.e. oxidation reactions and reduction reactions. The oxidation reaction which splits the hydrogen $(\mathrm{H} 2)$ bond into hydrogen ions $(\mathrm{H}+)$ and electrons (e-) takes place at the anode electrode. The reduction reactions then reduce the hydrogen ions $(\mathrm{H}+)$ into water $(\mathrm{H} 2 \mathrm{O})$ when oxygen ions $(\mathrm{O} 2)$ react with the hydrogen ions $(\mathrm{H}+)[18,19]$.

Typical electrode reactions are shown below using acetate as an example substrate:

Anodic reaction:

$\mathrm{CH}_{3} \mathrm{COOH}+2 \mathrm{H}_{2} \mathrm{O} \rightarrow 2 \mathrm{CO}+8 \mathrm{H}^{+}+8 \mathrm{e}^{-}$

Cathodic reaction:

$8 \mathrm{H}^{+}+8 \mathrm{e}^{-}+2 \mathrm{O}_{2} \rightarrow 4 \mathrm{H}_{2} \mathrm{O}$
Overall reaction:

$\mathrm{CH}_{3} \mathrm{COOH}+2 \mathrm{O}_{2} \rightarrow 2 \mathrm{H}_{2} \mathrm{O}+2 \mathrm{CO}_{2}$

In terms of cost comparison, the single chamber design is cheap and the materials used are readily available and can be locally sourced, making it the more suitable for the Nigerian society.

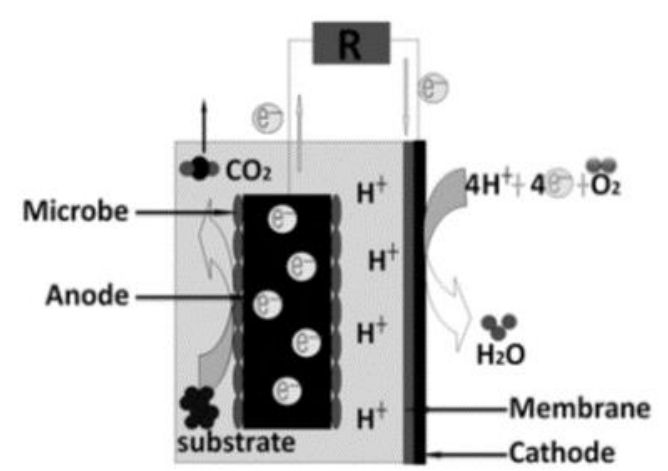

(a)

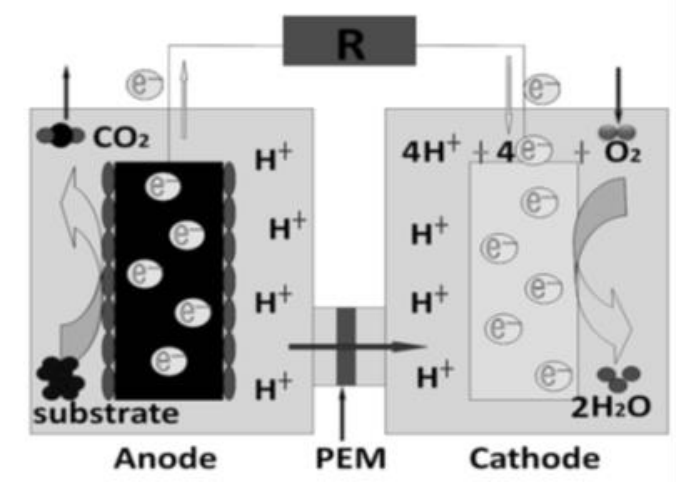

(b)

Figure 1: Schematic diagram of a microbial fuel cell (MFC). (a) Single chamber. (b) Two chamber

\section{Materials and Methods}

The materials and method applied in the execution of this work is tabulated and explained below.

Fresh cow dung was collected from a randomly selected cattle ranch in Benin City metropolis. The cow dung was then mixed with water in the ratio of $1: 1.75$. Scrap aluminium plates were collected from a manufacturing warehouse, cut and folded into multiple rectangular plates which were used as the anode electrode. Cylindrical graphite rods were purchased from a local dealer and the copper plate surrounding the graphite rods were scrapped off and used as the cathode electrode in the MFC. 8, 6 and 4 aluminium plates were together connected in series respectively. 8, 6 and 4 graphite rods were also together connected in series. Both series connections of the electrodes were placed in three separate plastic containers and prevented from touching each other with the use of a cut out rubber separator. The cow dung and water mixture was then charged into each plastic 
containers, thereby completing the microbial fuel cells. Each cell was monitored for the voltage and current output for a period of 28 days. An electrical multimeter was used to read the voltage and current output of the MFC; also, a pen-type $\mathrm{pH}$ meter was used to monitor the acidity and alkalinity of the organic matter as shown in Figure 2.

Table 1. Material used and their function

\begin{tabular}{|c|c|c|}
\hline $\mathbf{S} / \mathbf{N}$ & Material/Equipment & Function \\
\hline 1 & $\begin{array}{l}72 \text { polyethylene (PET) } \\
\text { bottles }\end{array}$ & $\begin{array}{l}\text { Each PET bottle functioned as } \\
\text { one MFC chamber }\end{array}$ \\
\hline 2 & $\begin{array}{l}\text { Electrodes (Aluminium } \\
\text { plates and cylindrical } \\
\text { graphite rods) }\end{array}$ & $\begin{array}{l}\text { The electrode is to establish the } \\
\text { presence of a potential } \\
\text { difference which the microbes } \\
\text { transfer the released electrons to. }\end{array}$ \\
\hline 3 & $\begin{array}{l}\text { Organic matter (cow } \\
\text { dung) }\end{array}$ & $\begin{array}{l}\text { The organic matter is the source } \\
\text { of fuel in the MFC. }\end{array}$ \\
\hline 4 & Flexible copper wires & $\begin{array}{l}\text { Connected between both } \\
\text { electrodes, its function is to } \\
\text { transfer the electrons deposited } \\
\text { at the anode electrode through } \\
\text { the equipment or machine to be } \\
\text { powered and then through to the } \\
\text { cathode electrode. }\end{array}$ \\
\hline 5 & LED bulbs & $\begin{array}{l}\text { Used to test the functionality of } \\
\text { the MFC. }\end{array}$ \\
\hline 6 & Pen-type $\mathrm{pH}$ meter & $\begin{array}{l}\text { Used to obtain the } \mathrm{pH} \text { value of } \\
\text { the organic matter. }\end{array}$ \\
\hline 7 & Electrical multimeter & $\begin{array}{l}\text { Used to obtain voltage and } \\
\text { current parameters of the } \\
\text { organic matter. }\end{array}$ \\
\hline
\end{tabular}

Mathematical formulae were used to obtain the values of parameters such as power and power density as expressed in (6) and (7) respectively.

Area of aluminium electrodes $\left(\mathrm{A}_{\mathrm{a}}\right)=2 \times 1 \mathrm{Xb}$

Area of graphite electrode $\left(\mathrm{A}_{\mathrm{g}}\right)=2 \pi \mathrm{r}(\mathrm{r}+\mathrm{h})$

Power $(\mathrm{P})=$ voltage $(\mathrm{V}) \mathrm{X}$ current $(\mathrm{I})$

i.e. $\mathrm{P}=\mathrm{VI}$

Power density $(\mathrm{PD})=\frac{\text { Power }(W)}{\text { Total surface area }(\mathrm{mm} 2)}$

Volume of containers (V)

= length (l) X breadth (b) X height (h)

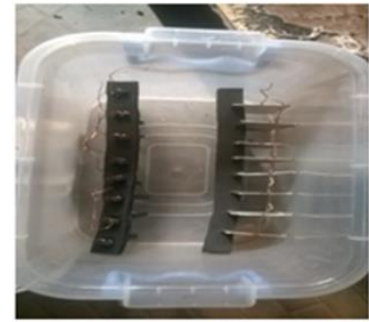

(a)

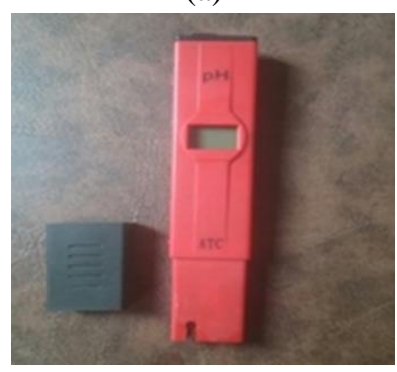

(c)

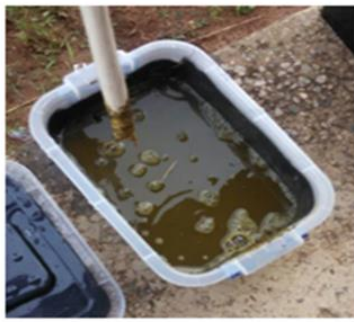

(b)

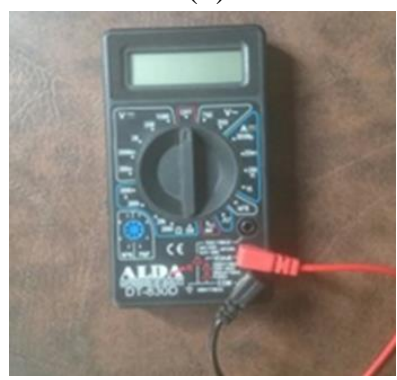

(d)
Figure 2. (a) MFC with 8 electrodes each of graphite rods and aluminium plates. (b) Mixture of cow dung with water used as electrolyte in MFCs (c) Pent-type $\mathrm{pH}$ meter used for monitoring acidity and alkalinity levels of the organic matter in the MFCs.

(d) Electrical multimeter used in reading the voltage and current output from the MFCs

\section{Results and Discussion}

The result of the experiments conducted was to investigate the current, voltage, power and power density of a membraneless MFC.

Table 2 shows the data obtained from the first MFC from experiment 1 . The $\mathrm{pH}$ value of the organic matter is seen to be acidic region i.e. $1-6.9$, indicating that the cell was acidic. There is a continued and progressive increase in the $\mathrm{pH}$ up to the value of 6.71 on the $11^{\text {th }}$ day when a change in the organic decomposition process occurred. A decrease in the $\mathrm{pH}$ value continued through the period under investigation to a $\mathrm{pH}$ value of 7.04. The maximum voltage recorded was $0.73 \mathrm{~V}$ with a corresponding current of $10.87 \mathrm{~mA}$ which also was the maximum current obtained. The voltage drop as obtained through the period under investigation was $0.47 \mathrm{~V}$. The total voltage and total current produced is $14.4 \mathrm{~V}$ and $168.1 \mathrm{~mA}$ respectively. A steady decline of power and power density was observed, with power and power density having a total value of $92.16 \mathrm{~mW}$ and $1.233 \mathrm{~mW} / \mathrm{mm}^{2}$ respectively. Figure 3 shows the curve pattern of $\mathrm{pH}$, voltage and current data obtained from the experiment conducted. The curve shows that a sudden climb in the $\mathrm{pH}$ value lead to an increase in the current generated. It can also be seen that in the acidic range i.e. $\mathrm{pH}$ values of $1-6.9$, an increase in the $\mathrm{pH}$ value lead to a decrease in the current generated. On the other hand in the basic range i.e. $\mathrm{pH}$ values of $7.1-14$, a decrease in the $\mathrm{pH}$ value lead to a corresponding decrease in the current generated. 
Table 2. Readings from Experiment 1 cell 1

\begin{tabular}{|c|c|c|c|c|c|}
\hline \multirow{8}{*}{$\begin{array}{c}\text { Sample } \\
\text { Description } \\
\text { and } \\
\text { Parameters }\end{array}$} & \multicolumn{5}{|c|}{$\begin{array}{l}\text { A fuel cell having eight (8) electrodes each connected in series. The cathode is graphite and } \\
\text { the anode aluminium. The electrolyte is cow dung mixed with water. }\end{array}$} \\
\hline & \multicolumn{5}{|c|}{ Average area of graphite electrode $=1.91$ square $\mathrm{cm}$} \\
\hline & \multicolumn{5}{|c|}{ Total area of graphite electrode $=15.26$ square $\mathrm{cm}$} \\
\hline & \multicolumn{5}{|c|}{ Average area of aluminium electrode $=30.94$ square $\mathrm{cm}$} \\
\hline & \multicolumn{5}{|c|}{ Total area of aluminium electrode $=247.5$ square $\mathrm{cm}$} \\
\hline & \multicolumn{5}{|c|}{ Mass of dung $=4 \mathrm{~kg}$} \\
\hline & \multicolumn{5}{|c|}{ Mass of water added $=1 \mathrm{~kg}$} \\
\hline & \multicolumn{5}{|c|}{ Total Mass $=5 \mathrm{~kg}$} \\
\hline Day & $\mathbf{p H}$ & Volt (V) & Current (mA) & Power (mW) & $\begin{array}{l}\text { Power Density } \\
\left(\mathrm{mW} / \mathrm{mm}^{2}\right)\end{array}$ \\
\hline 1 & 5.42 & 0.73 & 10.87 & 7.94 & 0.106 \\
\hline 2 & 5.57 & 0.72 & 10.53 & 7.58 & 0.101 \\
\hline 3 & 5.71 & 0.71 & 10.46 & 7.42 & 0.099 \\
\hline 4 & 5.96 & 0.65 & 8.63 & 5.61 & 0.075 \\
\hline 5 & 6.03 & 0.67 & 6.12 & 4.1 & 0.055 \\
\hline 6 & 6.14 & 0.68 & 6.2 & 4.22 & 0.057 \\
\hline 7 & 6.38 & 0.65 & 5.87 & 3.82 & 0.051 \\
\hline 8 & 6.41 & 0.65 & 4.81 & 3.13 & 0.042 \\
\hline 9 & 6.59 & 0.65 & 4.39 & 2.85 & 0.038 \\
\hline 10 & 6.71 & 0.6 & 4.2 & 2.52 & 0.034 \\
\hline 11 & 9.39 & 0.6 & 7.26 & 4.36 & 0.058 \\
\hline 12 & 9.17 & 0.55 & 6.38 & 3.51 & 0.047 \\
\hline 13 & 8.92 & 0.54 & 6.83 & 3.69 & 0.049 \\
\hline 14 & 8.83 & 0.53 & 6.67 & 3.54 & 0.047 \\
\hline 15 & 8.55 & 0.51 & 6.11 & 3.12 & 0.042 \\
\hline 16 & 8.31 & 0.5 & 6.53 & 3.27 & 0.043 \\
\hline 17 & 8.16 & 0.49 & 5.7 & 2.79 & 0.037 \\
\hline 18 & 7.97 & 0.48 & 5.4 & 2.59 & 0.035 \\
\hline 19 & 7.68 & 0.41 & 5.23 & 2.14 & 0.029 \\
\hline 20 & 7.42 & 0.41 & 5.59 & 2.29 & 0.031 \\
\hline 21 & 7.31 & 0.4 & 5.43 & 2.17 & 0.029 \\
\hline 22 & 7.25 & 0.39 & 4.32 & 1.68 & 0.023 \\
\hline 23 & 7.18 & 0.36 & 4.88 & 1.76 & 0.024 \\
\hline 24 & 7.14 & 0.35 & 5.21 & 1.82 & 0.024 \\
\hline 25 & 7.11 & 0.32 & 3.63 & 1.16 & 0.016 \\
\hline 26 & 7.09 & 0.32 & 3.72 & 1.19 & 0.016 \\
\hline 27 & 7.06 & 0.27 & 3.93 & 1.06 & 0.014 \\
\hline 28 & 7.04 & 0.26 & 3.2 & 0.83 & 0.011 \\
\hline Total & & 14.4 & 168.1 & 92.16 & 1.233 \\
\hline
\end{tabular}

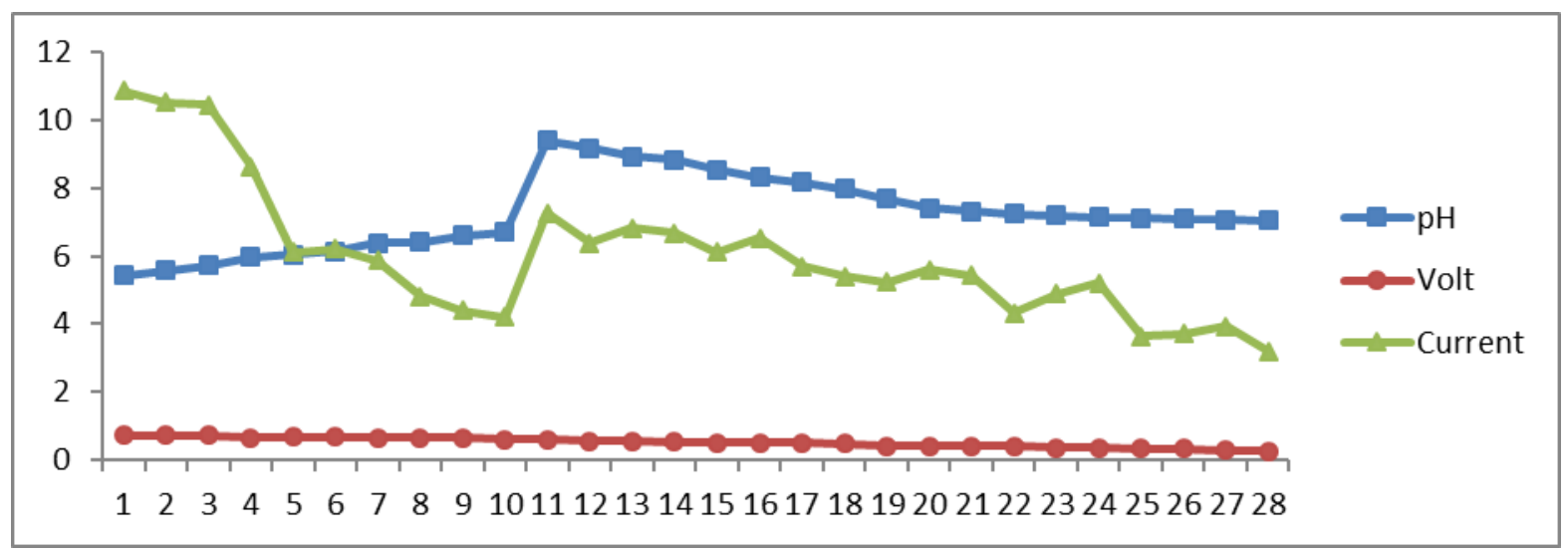

Figure 3. Graph of $\mathrm{pH}$, voltage and current readings from Table 2 
Table 3. Readings from Experiment 1 cell 2

\begin{tabular}{|c|c|c|c|c|c|}
\hline \multirow{8}{*}{$\begin{array}{l}\text { Sample } \\
\text { Description } \\
\text { and } \\
\text { Parameters }\end{array}$} & \multicolumn{5}{|c|}{$\begin{array}{l}\text { A fuel cell having six (6) electrodes each connected in series. The cathode is graphite and the } \\
\text { anode aluminium. The electrolyte is cow dung mixed with water. }\end{array}$} \\
\hline & \multicolumn{5}{|c|}{ Average area of graphite electrode $=2.29$ square $\mathrm{cm}$} \\
\hline & \multicolumn{5}{|c|}{ Total area of graphite electrode $=13.75$ square $\mathrm{cm}$} \\
\hline & \multicolumn{5}{|c|}{ Average area of aluminium electrode $=32.5$ square $\mathrm{cm}$} \\
\hline & \multicolumn{5}{|c|}{ Total area of aluminium electrode $=195$ square $\mathrm{cm}$} \\
\hline & \multicolumn{5}{|c|}{ Mass of dung $=4 \mathrm{~kg}$} \\
\hline & \multicolumn{5}{|c|}{ Mass of water added $=1 \mathrm{~kg}$} \\
\hline & \multicolumn{5}{|c|}{ Total Mass $=5 \mathrm{~kg}$} \\
\hline Day & pH & Volt (V) & Current (mA) & Power (mW) & $\begin{array}{l}\text { Power Density } \\
\left(\mathbf{m W} / \mathbf{m m}^{2}\right)\end{array}$ \\
\hline 1 & 5.53 & 0.7 & 9.82 & 6.31 & 0.110 \\
\hline 2 & 5.61 & 0.69 & 8.29 & 5.72 & 0.099 \\
\hline 3 & 5.73 & 0.67 & 7.02 & 4.7 & 0.081 \\
\hline 4 & 5.89 & 0.67 & 6.92 & 4.64 & 0.080 \\
\hline 5 & 6.01 & 0.67 & 5.73 & 3.84 & 0.066 \\
\hline 6 & 6.23 & 0.65 & 4.82 & 3.13 & 0.054 \\
\hline 7 & 6.47 & 0.65 & 5.88 & 3.82 & 0.066 \\
\hline 8 & 6.65 & 0.64 & 5.61 & 3.59 & 0.062 \\
\hline 9 & 6.86 & 0.64 & 5.83 & 3.59 & 0.062 \\
\hline 10 & 9.13 & 0.63 & 4.83 & 3.04 & 0.052 \\
\hline 11 & 9.47 & 0.61 & 8.15 & 4.97 & 0.086 \\
\hline 12 & 9.25 & 0.61 & 6.56 & 4.00 & 0.069 \\
\hline 13 & 9.11 & 0.6 & 6.24 & 3.74 & 0.064 \\
\hline 14 & 9.03 & 0.59 & 5.18 & 3.06 & 0.053 \\
\hline 15 & 8.97 & 0.55 & 6.84 & 3.76 & 0.065 \\
\hline 16 & 8.91 & 0.53 & 6.4 & 3.39 & 0.058 \\
\hline 17 & 8.63 & 0.52 & 5.66 & 2.94 & 0.051 \\
\hline 18 & 8.42 & 0.48 & 6.2 & 2.98 & 0.051 \\
\hline 19 & 8.27 & 0.48 & 5.88 & 2.82 & 0.049 \\
\hline 20 & 7.94 & 0.46 & 5.11 & 2.35 & 0.041 \\
\hline 21 & 7.68 & 0.46 & 4.8 & 2.21 & 0.038 \\
\hline 22 & 7.31 & 0.41 & 4.75 & 1.95 & 0.034 \\
\hline 23 & 7.23 & 0.41 & 5.29 & 2.17 & 0.037 \\
\hline 24 & 7.21 & 0.37 & 5.63 & 2.08 & 0.036 \\
\hline 25 & 7.20 & 0.36 & 4.52 & 1.63 & 0.028 \\
\hline 26 & 7.19 & 0.32 & 4.4 & 1.41 & 0.024 \\
\hline 27 & 7.16 & 0.3 & 4.57 & 1.37 & 0.024 \\
\hline 28 & 7.12 & 0.3 & 3.22 & 0.97 & 0.018 \\
\hline Total & & 14.97 & 164.15 & 90.18 & 1.558 \\
\hline
\end{tabular}

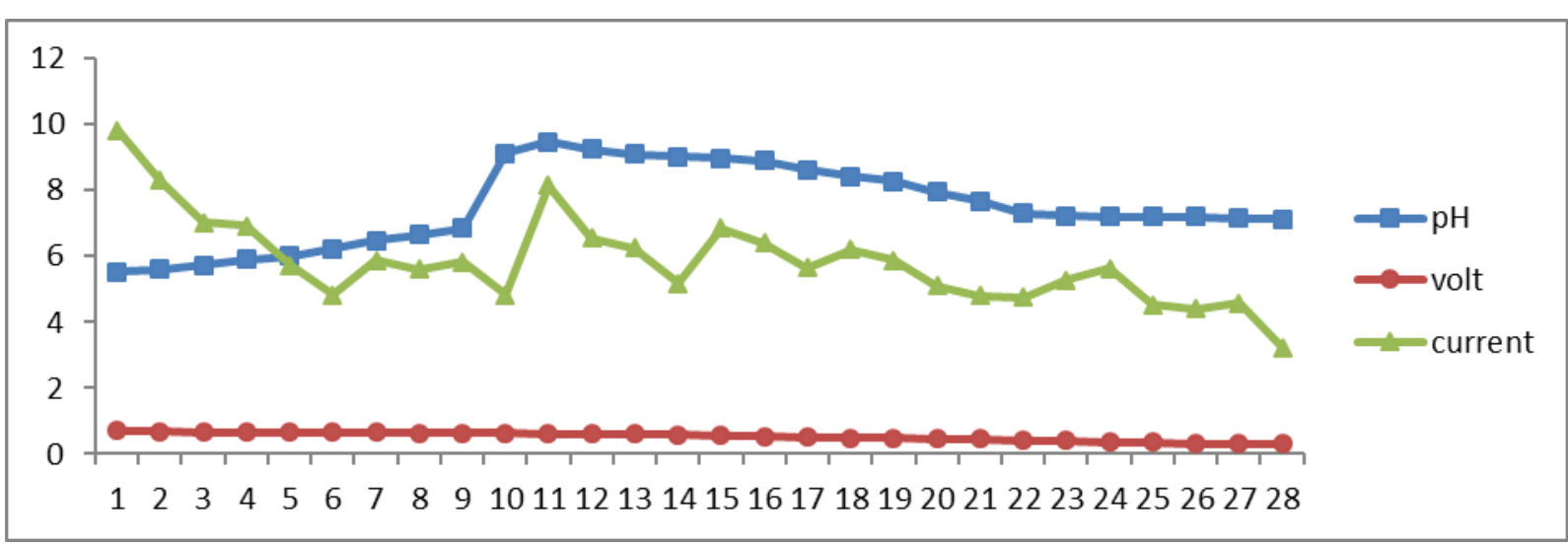

Figure 4. Graph of pH, voltage and current readings from Table 3 
Table 4. Readings from Experiment 1 cell 3

\begin{tabular}{|c|c|c|c|c|c|}
\hline \multirow{8}{*}{$\begin{array}{l}\text { Sample } \\
\text { Description } \\
\text { and } \\
\text { Parameters }\end{array}$} & \multicolumn{5}{|c|}{$\begin{array}{l}\text { A fuel cell having four (4) electrodes each connected in series. The cathode is graphite and the } \\
\text { anode aluminium. The electrolyte is cow dung mixed with water. }\end{array}$} \\
\hline & \multicolumn{5}{|c|}{ Average area of graphite electrode $=2.19$ square $\mathrm{cm}$} \\
\hline & \multicolumn{5}{|c|}{ Total area of graphite electrode $=8.77 \mathrm{~cm}$} \\
\hline & \multicolumn{5}{|c|}{ Average area of aluminium electrode $=29.5$ square $\mathrm{cm}$} \\
\hline & \multicolumn{5}{|c|}{ Total area of aluminium electrode $=118$ square $\mathrm{cm}$} \\
\hline & \multicolumn{5}{|c|}{ Mass of dung $=4 \mathrm{~kg}$} \\
\hline & \multicolumn{5}{|c|}{ Mass of water added $=1 \mathrm{~kg}$} \\
\hline & \multicolumn{5}{|c|}{ Total Mass $=5 \mathrm{~kg}$} \\
\hline Day & pH & Volt (V) & Current (mA) & Power (mW) & $\begin{array}{l}\text { Power Density } \\
\left(\mathbf{m W} / \mathbf{m m}^{2}\right)\end{array}$ \\
\hline 1 & 5.48 & 0.69 & 9.96 & 6.87 & 0.190 \\
\hline 2 & 5.66 & 0.67 & 9.76 & 6.54 & 0.180 \\
\hline 3 & 5.93 & 0.67 & 9.53 & 6.39 & 0.180 \\
\hline 4 & 6.27 & 0.67 & 8.82 & 5.91 & 0.160 \\
\hline 5 & 6.41 & 0.64 & 7.53 & 4.82 & 0.130 \\
\hline 6 & 6.54 & 0.63 & 6.63 & 4.18 & 0.110 \\
\hline 7 & 6.62 & 0.62 & 6.43 & 3.99 & 0.110 \\
\hline 8 & 6.73 & 0.58 & 5.32 & 3.09 & 0.085 \\
\hline 9 & 6.88 & 0.57 & 6.01 & 3.43 & 0.094 \\
\hline 10 & 8.76 & 0.57 & 6.15 & 3.51 & 0.096 \\
\hline 11 & 9.31 & 0.52 & 8.63 & 4.49 & 0.120 \\
\hline 12 & 9.11 & 0.52 & 8.15 & 4.24 & 0.120 \\
\hline 13 & 8.86 & 0.51 & 6.78 & 3.48 & 0.096 \\
\hline 14 & 8.77 & 0.51 & 6.16 & 3.14 & 0.086 \\
\hline 15 & 8.63 & 0.51 & 6.05 & 3.09 & 0.085 \\
\hline 16 & 8.52 & 0.5 & 5.58 & 2.79 & 0.077 \\
\hline 17 & 8.44 & 0.49 & 6.11 & 2.99 & 0.082 \\
\hline 18 & 8.19 & 0.47 & 5.23 & 2.46 & 0.068 \\
\hline 19 & 7.91 & 0.47 & 5.21 & 2.45 & 0.067 \\
\hline 20 & 7.83 & 0.45 & 5.09 & 2.29 & 0.063 \\
\hline 21 & 7.67 & 0.43 & 4.93 & 2.13 & 0.059 \\
\hline 22 & 7.48 & 0.42 & 4.51 & 1.89 & 0.052 \\
\hline 23 & 7.39 & 0.41 & 4.31 & 1.77 & 0.049 \\
\hline 24 & 7.31 & 0.41 & 3.88 & 1.59 & 0.044 \\
\hline 25 & 7.27 & 0.41 & 3.57 & 1.46 & 0.040 \\
\hline 26 & 7.22 & 0.38 & 3.31 & 1.26 & 0.035 \\
\hline 27 & 7.17 & 0.35 & 3.26 & 1.14 & 0.031 \\
\hline 28 & 7.13 & 0.34 & 3.08 & 1.05 & 0.029 \\
\hline Total & & 14.41 & 169.88 & 92.44 & 2.538 \\
\hline
\end{tabular}

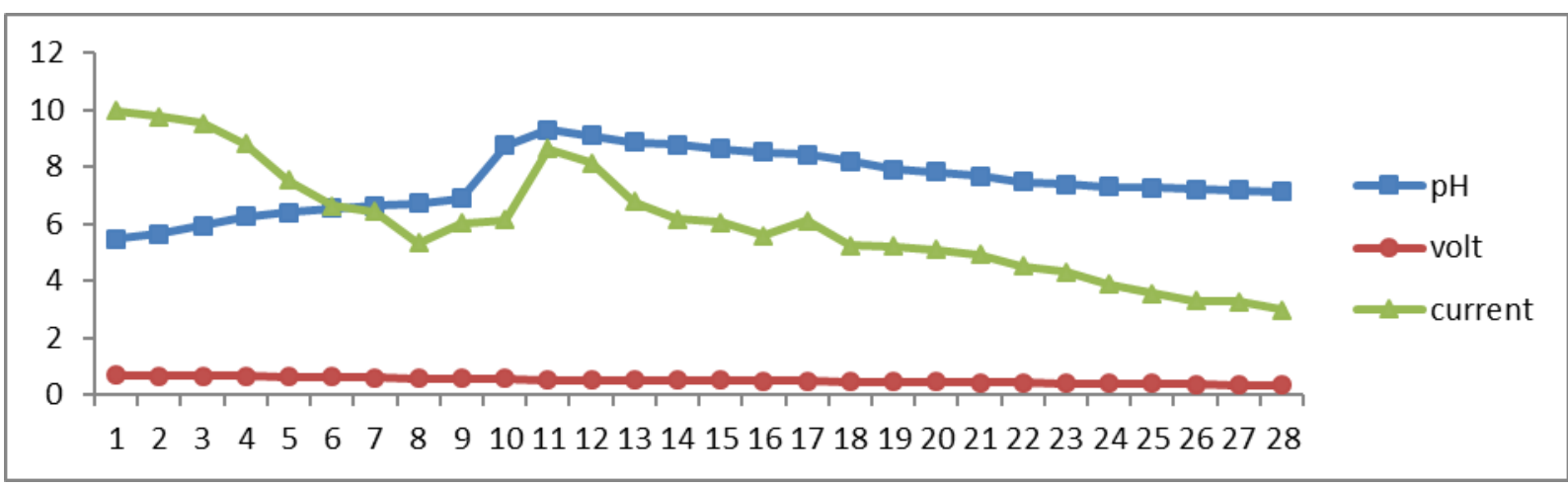

Figure 5. Graph of $\mathrm{pH}$, voltage and current readings from Table 4 
Table 3 showed a significant change in the $\mathrm{pH}$ value in the $10^{\text {th }}$ day from a value of 6.86 to 9.13 followed by a steady and gradual decrease to a value of 7.12. The maximum voltage obtained was $0.7 \mathrm{~V}$ with a corresponding maximum current of $9.82 \mathrm{~mA}$. The minimum voltage and minimum current obtained were $0.3 \mathrm{~V}$ and $3.22 \mathrm{~mA}$ respectively. The voltage drop was $0.4 \mathrm{~V}$ during the period under investigation. The total voltage and total current obtained were $14.97 \mathrm{~V}$ and $164.15 \mathrm{~mA}$ respectively. Gradual and steady decrease in the power and power density were observed. Total power and total power density obtained were of $90.18 \mathrm{~mW}$ and $1.558 \mathrm{~mW} / \mathrm{mm}^{2}$. Figure 4 show the curve pattern of $\mathrm{pH}$, voltage and current data obtained from the experiment conducted. The graph shows the current having a fluctuating but decreasing trend. The voltage showed a steady and gradual decrease. The $\mathrm{pH}$ showed a steady and gradual increase until a sudden climb followed by a gradual decrease. Table 4 showed that the minimum $\mathrm{pH}$ value of 5.48 had corresponding maximum voltage, maximum current, maximum power and maximum power density of $0.69 \mathrm{~V}$, $9.96 \mathrm{~mA}, 6.87 \mathrm{~mW}$ and $0.19 \mathrm{mw} / \mathrm{mm}^{2}$. The maximum and minimum voltage obtained were $0.69 \mathrm{~V}$ and $0.34 \mathrm{~V}$ respectively. The voltage drop in the cell during the period under investigation was $0.35 \mathrm{~V}$. The maximum and minimum power obtained were $6.87 \mathrm{~mW}$ and $1.05 \mathrm{~mW}$ respectively. The maximum and minimum power density obtained was $0.19 \mathrm{~mW} / \mathrm{mm}^{2}$ and $0.029 \mathrm{~mW} / \mathrm{mm}^{2}$ respectively. The total voltage, total current, total power and total power density obtained were $14.41 \mathrm{~V}, 169.88 \mathrm{~mA}, 92.44 \mathrm{~mW}$ and $2.538 \mathrm{~mW} / \mathrm{mm}^{2}$ respectively. Figure 5 shows the curve patterns exhibited by the $\mathrm{pH}$, voltage and current data obtained. The voltage curve pattern shows a gradual and steady decrease. A gradual and steady increase of $\mathrm{pH}$ was observed followed by a sudden climb to a value of 8.76 from which a gradual and steady decrease during the period under investigation. The curve pattern exhibited by the current showed a decrease followed by a sudden climb which was then accompanied by a gradual fall. The graph shows one point of intersection between the $\mathrm{pH}$ and current curves. The point of intersection occurred at a value of 6.59 .

Figure 6 shows the total voltage output obtained from built MFCs having 8, 6 and 4 electrodes respectively. The minimum total voltage obtained from the cell was $14.4 \mathrm{~V}$, giving an average daily voltage output from each cell of $0.52 \mathrm{~V}$.

The total current output obtained from the MFCs having 8, 6 and 4 electrodes were $168.1 \mathrm{~mA}, 164.15 \mathrm{~mA}$ and $169.88 \mathrm{~mA}$ respectively as shown in Figure 7 . The average current obtained from the cells was $167.38 \mathrm{~mA}$, giving a daily average current output of $5.98 \mathrm{~mA}$.

Figure 8 above shows the total power output obtained from each MFC. The maximum power output obtained is
$92.44 \mathrm{~mW}$. The average power output obtained from the three MFCs was $91.59 \mathrm{~mW}$, giving a daily average power output of $3.27 \mathrm{~mW}$.

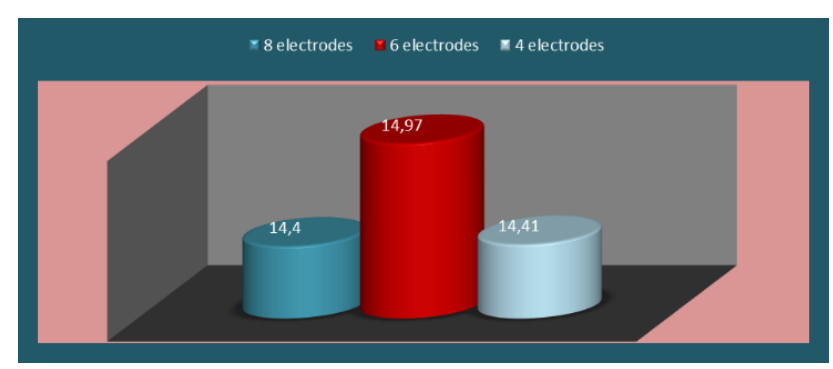

Figure 6. Histogram showing the total voltage output from single slurry (organic matter) MFCs with 8, 6 and 4 electrodes

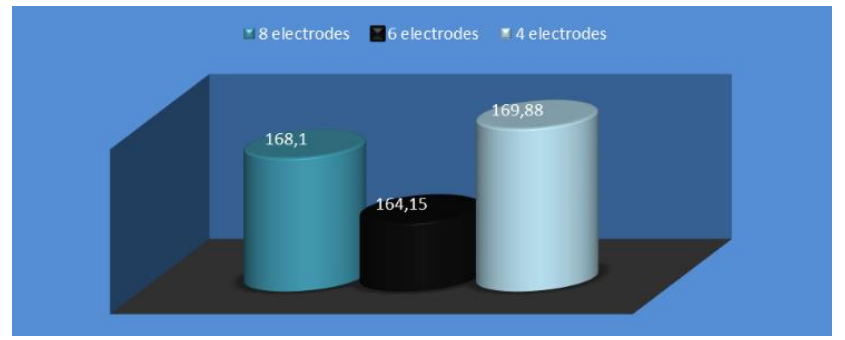

Figure 7. Histogram showing the total current output from single slurry (organic matter) MFCs with 8, 6 and 4 electrodes

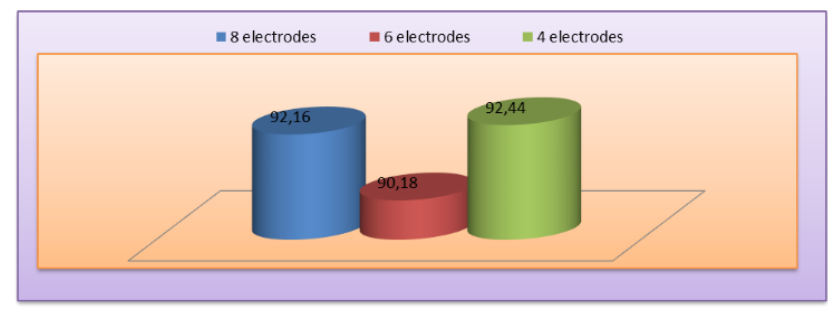

Figure 8. Histogram showing the total power output from a single slurry (organic matter) MFCs with 8, 6 and 4 electrodes

\section{Discussion}

From Table 2, Table 3 and Table 4, the surface area of electrode had an effect on the output of the MFC. It was observed that the maximum voltage, current and power and maximum average power density was obtained in the MFC having the larger surface area of electrode. The result indicated that the MFC with the largest surface area of electrode had the highest voltage drop of $0.47 \mathrm{~V}$. This could be as a result of the microbes having more electrode surface area to attach themselves to, thereby transferring more energy.

From Figure 3, Figure 4 and Figure 5 exhibited similar curve patterns indicating that the organic matter undergone through the decomposition process and also the current output is dependent on the stages of these processes. 
In the study carried out, there was no change in polarity of the electrodes as the organic decomposition stages were taking effect, however, there was an increase in the current output with respect to the $\mathrm{pH}$ value changing from the acidity to alkalinity. Figure 4 and Figure 5 indicated that the total average voltage and current output generated per day from the MFCs is $0.52 \mathrm{~V}$ and $5.98 \mathrm{~mA}$ respectively, indicating that the average power output per day from the MFCs is $3.11 \mathrm{~mW}$. The functionality of the MFCs was tested by using it to power LED indicator bulbs. The LED bulbs were lit and were clearly visible up to a distance of 30 meters at daytime. Although the LED bulbs remained functional from the power generated by the MFCs, the brightness gradually and steadily diminished.

The power output from the MFC under the period of investigation was not affected or diminished by the its use in powering up or lighting the LED indicator bulbs, rather the power output from the MFC was as a result of the decomposition of the organic matter by the microbes. This implies that the organic decomposition rate of the organic matter in a microbial fuel cell (MFC) is not affected by the usage of the power generated. The fluctuations of both voltage and current readings may be as a result of the change of microbes responsible for the decomposition of the organic waste i.e. the microbes responsible for the hydrolysis stage is not same responsible for the acidogenesis stage (different microbes are responsible for the decomposition of the organic waste at different stages).

\section{Conclusion}

Cow dung was investigated to examine its potential as a source for generating electrical energy with a single chamber MFC and the result indicated it is a viable resource for power generation when used in a single chamber MFC. Results obtained showed that the highest power obtained for the three cells were in the acidic region of the $\mathrm{pH}$ value. The result also indicated that amongst other factors, for equal volume of organic matter, output voltage, output current and output power were affected by the surface area of electrodes. With the daily average voltage output, current output and power output obtained from the use of cow dung in a single chamber MFC, there was high potential for use in domestic applications as well as road traffic lights if scaled up. The LED bulb requires a minimum power of $2 \mathrm{~mW}$ for operation. To operate a road traffic light using energy obtained from a single chamber MFC with a mixture of cow dung and water as electrolyte, road traffic lights can be redesigned to operate on the energy output from MFC, thereby making all road traffic lights run on renewable energy from organic source. Moreover, reading lamps and geographical sensors. can also be redesign to run on the energy produced from single chamber MFC using cow dung as electrolyte.

\section{References}

[1] Bhattacharyya S.C. (2011). "Energy Economics". DOI: 10.1007/978-0-85729-268 1_2, SpringerVerlag London Limited 2011.

[2] Chima Ngumah, Jude Ogbulie, Justina Orji and Ekpewerechi Amadi (2016). "Potential of Organic Waste for Biogas and Biofertilizer Production in Nigeria”. Environmental Research, Engineering and Management. No.1(63). Pages: 60-66. ISSN: 20292139.

[3] Eva Pongrácz (2002). "Re-Defining the Concepts of Waste and Waste Management: Evolving the Theory of Waste Management". ISBN: 951-426821-0.

[4] Kun Guo, Daniel J. Hassettb and Tingyue Guc (2012). "Microbial Fuel Cells: Electricity Generation from Organic Wastes By Microbes". ISBN: 978-1845939564, Pages: 164-189. CAB International, Oxon. United Kingdom.

[5] Logan B.E., Hamelers B., Rozendal R., Schröder U., Keller J., Freguia S., Aelterman P., Verstraete W., Rabaey K. (2006). "Microbial Fuel Cells: Methodology and Technology". Environmental Science and Technology 40, 5181-5192.

[6] Mbalisi O.F. and Offor B.O. (2015). "Energy Crisis and Its Effects on National Development: The Need for Environmental Education In Nigeria". British Journal of Education. Vol. 3, No.1, Pp. 21-37.

[7] Mostafa Rahimnejad, Arash Adhami, Soheil Darvari, Alireza Zirepour and Sang-Eun Oh (2015). "Microbial fuel cell as new technology for bioelectricity generation: A review". Alexandria Engineering Journal. Vol. 54. Pages: 745-756.

[8] OECD ((2012). "Green Growth and Developing Countries a Summary for Policy Makers". OECD, Paris.

[9] Ogwueleka T., (2009). "Municipal Solid Waste Characteristics and Management In Nigeria". Iranian Journal of Environment Health Science Engineering Vol. 6, No. 3, pp. 173-180.

[10] Osueke C.O. and Ezugwu C.A.K. (2011). "Study of Nigeria Energy Resource and Its Consumption". International Journal of Scientific and Engineering Research, Vol. 2, Issue 12. ISSN: 2229-5518.

[11] Oyeniyi, B. A. (2011). "Waste Management in Contemporary Nigeria: The Abuja Example". International Journal of Politics and Good Governance Volume 2, No 2.2, ISSN: 0976-1195.

[12] Ola E. Aluko (2012). "Environmental Degradation and the Lingering Threat of Refuse and Pollution in Lagos State". Journal of Management and Sustainability Vol. 2, No. 1. Pages: 217-226.

[13] Ezugwu C.N. (2015). "Renewable Energy Resources in Nigeria: Sources, Problems and 
Prospects". Journal of Clean Energy Technologies,

Vol. 3, No. 1. DOI: 10.7763/JOCET.2015.V3.171.

[14] Rebecca M.H., Sophus A.R., Polina D., Amram M. (2018). "Climate Change in 2018: Implications for Business". Harvard Business School. ISSN: 9-317032.

[15] Michaela Bobeck (2010). "Organic Household Waste in Developing Countries". Mid Sweden University.

[16] Shaikh J., Niranjan P., and Rituja P. (2016). "Microbial Fuel Cell: Design and Operation". Research and Reviews: Journal of Microbiology and Biotechnology. -ISSN: 2320-3528.

[17] Sourish K., Kanika K., and Subir K. (2010). "Design and Development of Microbial Fuel cells". Current Research, Technology and Education Topics in Applied Microbiology and Microbial Biotechnoology. Pages: 1029-1034.

[18] Melanie K. and Teko W.N. (2010). "SingleChamber Solid Oxide Fuel Cell Technology - From Its Origins to Today's State of the Art". Energies. Vol. 3, Pages: 57-134; DOI: 10.3390/en3010057.

[19] Surajit D. and Neelam M. (2010). "Recent Development in Microbial Fuel Cells: A Review". Journal of Scientific and Industrial Research. Vol. 69. Pages: 727-731. 